\title{
Boys with Internalizing and Externalizing Behavior Problems: A Case Control Study
}

\author{
Alessandra Turini Bolsoni-Silva ${ }^{*}, 1$ \\ Orcid.org/0000-0001-8091-9583 \\ Sonia Regina Loureiro ${ }^{2}$ \\ Orcid.org/0000-0001-9423-2897 \\ ${ }^{1}$ Universidade Estadual Paulista, Bauru, São Paulo, Brasil \\ ${ }^{2}$ Universidade de São Paulo, Ribeirão Preto, São Paulo, Brasil
}

\begin{abstract}
The simultaneous occurrence of internalizing and externalizing behavior problems characterizes a risk to the child's development in clinical terms and requires more studies. The objective was to correlate, from the evaluation of the biological mothers, child social skills, resources of the family environment and parenting practices for a group of boys who presented both internalizing and externalizing behavior problems, in comparison to a paired group of children without behavior problems. A case-control design was adopted, with 36 biological mothers of boys who were distributed in two groups, G1 - 18 boys identified with behavior problems (clinical) and $\mathrm{G} 2-18$ boys identified without behavior problems (nonclinical). The mothers completed instruments regarding parental practices, environment resources and child behaviors. In the clinical group, a significantly greater use of negative practices (especially "hitting") was identified, as well as a deficit of positive practices and a lack of resources of the family environment. Correlations showed that, in the nonclinical group, positive practices were associated with skilled behaviors, whereas negative practices were associated with problem behaviors - although this did not happened in the clinical group. This suggests a lack of consistence in the application of these practices in this group. These data contribute to planning guidance practices for parents.
\end{abstract}

Keywords: Behavior problems, social skills, parental practices.

\section{Meninos com Problemas de Comportamento Internalizantes e Externalizantes: Um Estudo de Caso Controle}

\section{Resumo}

Em termos clínicos, a ocorrência simultânea de problemas de comportamento internalizantes e externalizantes caracteriza risco ao desenvolvimento infantil, carecendo de mais estudos. Objetivou-se correlacionar, a partir da avaliação de mães biológicas, as habilidades sociais infantis, os recursos do

* Mailing address: Universidade Estadual Paulista, Faculdade de Ciências, Campus de Bauru, Av. Eng. Luiz Edmundo Carrijo Coube, 14-01, Vargem Limpa, Bauru, SP, Brazil 17033-360. Phone (14) 3103-6087; (14) 99743-7024. E-mail: bolsoni.silva@unesp.br.

Support: Conselho Nacional de Desenvolvimento Científico e Tecnológico (CNPq) - Bolsa de Produtividade em Pesquisa, Fundação de Amparo à Pesquisa do Estado de São Paulo (FAPESP). 
ambiente familiar e as práticas educativas parentais para um grupo de meninos que apresentam simultaneamente problemas de comportamento internalizantes e externalizantes, em comparação a um grupo pareado de crianças sem problemas comportamentais. Adotou-se um delineamento caso-controle, sendo participantes 36 mães biológicas de meninos que foram distribuídos em dois grupos, G1 - 18 meninos identificados com problema de comportamento (clínico) e G2 - 18 meninos identificados sem problema de comportamento (não clínico). As mães responderam a instrumentos sobre práticas parentais, recursos do ambiente e comportamentos infantis. No grupo clínico, foi identificado significativamente um maior uso de práticas negativas (especialmente o bater), déficits de práticas positivas e menos recursos do ambiente familiar. As correlações mostraram que no grupo não clínico as práticas positivas foram associadas aos comportamentos habilidosos e as práticas negativas aos comportamentos problema, o que não ocorreu no grupo clínico, sugerindo falta de consistência na aplicação das práticas nesse grupo. Tais dados contribuem para o planejamento de práticas de orientação de pais.

Palavras-chave: Problemas de comportamento, habilidades sociais, práticas parentais.

\section{Niños con Problemas de Comportamiento Internalizantes y Externalizantes: Un Estudio de Caso de Control}

\section{Resumen}

La ocurrencia simultánea de problemas de comportamiento internalizantes y externalizantes caracteriza riesgo al desarrollo infantil, careciendo de más estudios. Se objetivó correlacionar, las habilidades sociales infantiles, los recursos del ambiente familiar y las prácticas educativas parentales para un grupo de niños que presentan simultáneamente problemas de comportamiento internalizantes y externalizantes, en comparación con un grupo pareado niños sin problemas de comportamiento. En el caso de los niños que se distribuyeron en dos grupos, G1 - 18 varones identificados con problema de comportamiento (clínico) y G2 - 18 niños identificados sin problema de comportamiento (no clínico), se observó un delineamiento caso-control, siendo participantes 36 madres biológicas de niños que fueron distribuidos en dos grupos. Las madres respondieron a instrumentos sobre prácticas parentales, recursos del ambiente y comportamientos infantiles. En el grupo clínico, se identificó un mayor uso de prácticas negativas, déficit de prácticas positivas y menos recursos del ambiente familiar. Las correlaciones mostró que en el grupo no clínico las prácticas positivas fueron asociadas a los comportamientos hábiles y las prácticas negativas a los comportamientos problema. Estos datos contribuyen a la planificación de las prácticas de orientación de los padres.

Palabras clave: Problemas de comportamiento, habilidades sociales, prácticas parentales.

The prevention of future mental health problems may be favored by monitoring childhood development, especially by the early identification of behavior problems. Behavior problems are multidetermined and among the factors that influence them are the parental practices and the child's social skills (BolsoniSilva \& Loureiro, 2011). For Achenbach and Rescorla(2001) these problems can be understood as externalizing, such as disobedience, challenge/ opposition and aggressiveness, and internalizing, expressed as anxiety, depression and somatic complications. The presence of behavior problems is associated with impairments in the promotion of the development and acquisition of new behaviors relevant to learning (BolsoniSilva, Loureiro, \& Marturano, 2016b). Patterson, Reid, and Dishion (1992) found that boys with externalizing behavior problems in early childhood are at higher risk of becoming antisocial in adolescence. Similarly, internalizing problems in childhood may evolve into anxiety and depression disorders, associated with other comorbidities (Flett \& Hewitt, 2013). 
In the Brazilian context, Bolsoni-Silva, Silveira, Cunha, Silva, and Orti (2016), studied a community sample of 291 children (boys and girls, preschool and school aged children), identified through the evaluation of their teachers based on the Teacher's Report Form (TRF), verifying that $63.30 \%$ of the preschool aged boys, $23.81 \%$ of the preschool aged girls, $67.87 \%$ of the school aged boys and $28.57 \%$ of the school aged girls presented some type of behavior problem (internalizing, externalizing or both). The study found that the boys had more behavior problems, highlighting affective problems, pervasive development problems, ADHD (Attention Deficit and Hyperactivity Disorder) problems, oppositional defiant problems, attention problems, rule-breaking behavior, aggressive behavior, and conduct problems. They emphasized that among the boys there was more internalizing and externalizing comorbidity in both the preschool (28.33\%) and school aged children (28.57\%).

Martin, Granero, and Ezpeleta (2014), with a community-based sample, studied the comorbidity of oppositional problems and anxiety disorder of 622 children assessed at 3 and 5 years of age, distributed in three groups, these being, only opposition behavior, only anxiety disorder and both. They found that oppositional behavior associated with anxiety disorder was associated with a higher risk of school problems and other problems.

Considering the studies of Bolsoni-Silva et al. (2016) and Martin et al. (2014), with community-based samples, a high occurrence of behavior problems correlated with academic difficulties can be seen. The simultaneous occurrence of internalizing and externalizing problems, according to Martin et al. (2014) puts the child at greater risk for the development of other problems. In this sense, there is an evident need to broaden the understanding of these behaviors by verifying their associations with other variables in the context of children's development, in order to identify clues that favor the prevention and remediation of these difficulties. These variables include the conditions of the family environment. The relevance of the family environment resources for the behaviors of children is recognized in the literature, as is the use of positive parenting practices, by providing a playful environment and supervising homework (Marturano, 2006).

Aiming to identify the influence of parentchild interactions on parental stress and behavior problems, Vaughan, Feinn, Bernard, Brereton, and Kaufman (2013) evaluated a sample of 177 children and youths (ages 5-18 years, mean age 12 years) and their caregivers who attended a school care system in Bridgeport, Connecticut. The youths were organized into four groups according to the CBCL "Child Behavior Checklist" (Achenbach \& Rescorla, 2001), these being: without behavior problems, with internalizing problems only, with externalizing problems only and with both externalizing and internalizing problems. It was found that the dysfunctional interactions of the parents correlated positively with the children considered difficult, with simultaneous internalizing and externalizing problems. The authors also reported that the parents of the children who presented internalizing and externalizing problems simultaneously reported significantly more distress and stress compared to the parents of children with externalizing or internalizing problems only or no behavior problems. They emphasized the relevance of the mutual influence of parental anguish and the children's problems for the parent-child interactions, which evidences the need to consider parental practices as a relevant element for the understanding of the child's behaviors.

Among the variables that seem to increase or reduce the occurrence of problems, sociodemographic variables such as the gender of the child (Bayer, Sanson, \& Hemphill, 2006), positive and negative parenting practices (Barbot, Crossman, Hunter, Grigorenko, \& Luthar, 2014) and the socially skillful behaviors of the children (Blandon, Calkins, \& Keane, 2010; BolsoniSilva, Loureiro, \& Marturano, 2016a, 2016b) have been highlighted. A strong association between positive practices and the child's social skills (Borden et al., 2014) and between behavior problems and negative practices (Bolsoni- 
Silva et al., 2016; Borden et al., 2014) has been documented in the literature. Parenting practices are behaviors that support parental supervision and the manifestation of affection and emotional support, collaborating for the teaching of moral behavior (Gomide, 2006). Parenting practices or Parenting Social Skills (PSSs) are behaviors applied in the parent-child interactions that maximize the development of satisfying social interactions, including behaviors of communication, manifestation of affection and establishing of limits (Bolsoni-Silva \& Loureiro, 2011). Empirical studies have shown that families of children who do not present behavior problems present more PSSs and less negative practices, however, these studies did not address the simultaneous presence of externalizing and internalizing problems (Bolsoni-Silva \& Loureiro, 2011; Rovaris, 2015).

In the study of Bolsoni-Silva and Loureiro (2011), using the Educative Social Skills Interview Scrip (ESS-IS-P) and the CBCL to assess, respectively, parenting practices and behavior problems of preschool children with $(n=27)$ and without behavior problems $(n=26)$, married and separated families were included. It was verified that neither the negative nor positive practices, as a total score, differentiated the groups, however some positive practices differentiated them. These included expressing negative feelings, expressing positive feelings, talking about right and wrong, parental agreement, establishing limits to control the behavior of the child and identifying behaviors considered appropriate. Positive practices including communication, affection, and limits were also associated with fewer behavior problems in other studies (Berry \& O'Connor, 2010; Borden et al., 2014).

In relation to the use of negative practices to raise children, such as physical punishment, several studies have found association with externalizing (Price, Chiapa, \& Walsh, 2013; Trepat, Granero, \& Ezpeleta, 2014) and internalizing problems (Xing \& Wang, 2013). In groups of children with internalizing problems only, studies have indicated some specific characteristics of the parental practices, such as communication problems (Tandon, Cardeli, \& Luby, 2009), lack of responsiveness and affection (Orti, Bolsoni-Silva, \& Vila, 2015; Tandon et al., 2009), excess of control/criticism/demands (Orti et al., 2015; Tandon et al., 2009), overprotection and failure in the teaching of autonomy (Tandon et al., 2009), excessive use of negative practices (Bolsoni-Silva et al., 2016; Tandon et al., 2009) and also in rigidity in establishing rules with little use of flexibility (Orti et al., 2015).

The present study focused on boys that presented more behavior problems, including comorbidities. Analyzing the literature, this review verified that more frequently studies address the specific patterns of parents' and children's behavior considering children with behavior problems in general or only with internalizing or externalizing problems. However, there is a lack of case-control studies that map parenting practices and childhood social skills in the interactions with children that present the simultaneous occurrence of internalizing and externalizing problems. The present study aimed to fill this gap by proposing, through a casecontrol design, to compare and correlate parenting practices and childhood social skills, exclusively with boys, who presented internalizing and externalizing problems simultaneously. The present study focused exclusively on boys who presented more behavior problems, including comorbidities (Bolsoni-Silva, Levatti, Guidugli, \& Marim, 2015; Bolsoni-Silva et al., 2016), with the adoption of a paired group regarding the variables of the families and children, in order to avoid bias.

\section{Objective}

The aim of this study was to correlate, from the evaluation of the biological mothers, childhood social skills, resources of the family environment and parenting practices for a group of preschool and school aged children who presented the simultaneous occurrence of internalizing and externalizing behavior problems, compared to a paired group of children with no behavior problems. 


\section{Method}

A cross-sectional, correlational design with comparison between paired groups was used (Cozby, 2003).

\section{Participants}

A convenience sample of 36 mothers and their biological children, boys, from biparental families, were distributed in two paired groups, these being: G1, with 18 boys with internalizing and externalizing behavior problems ( 8 preschool and 10 school aged children), considered clinical according to the CBCL criteria (Achenbach \& Rescorla, 2001), completed by their mothers, and $\mathrm{G} 2$, with 18 boys ( 8 preschool and 10 school aged children) with no behavior problems, considered nonclinical, according to the same criteria. The mean age of the preschool children was 4 years $(S D=1.13)$ and 8 years 6 months $(S D=1.91)$ for the school children. The mean age of the mothers of the preschool children was 22 years $(S D=14.7)$ and 26 years $(S D=16.44)$ for the mothers of the school children. There were no differences in this distribution $\left(x^{2}=18.450, p=.240\right)$.

In order to guarantee control of possible biases in the sample: (a) only mothers/women married or living in a consensual union, guaranteeing a biparental family configuration; (b) the same number of preschool and school age children; and (c) only boys were included in the two groups. Furthermore, it was sought to homogenize the characteristics of the preschool and school aged children regarding the variables: maternal education, family income and number of children living in the household. In the comparisons between the preschool and school children, no significant differences were identified regarding: (a) maternal education $\left(x^{2}=0.563\right.$, $p=.453$ ), with a predominance of 12 years of schooling, ranging from 4 to 16; (b) income $\left(x^{2}=3.365, p=.186\right)$, with a predominance of income equivalent to two minimum wages; and (c) the number of children living in the household $\left(x^{2}=1.417, p=.492\right)$, with two children per family predominating. Considering the homogeneity of the groups of school and preschool children regarding the sociodemographic variables, they were treated as a single group in the study. In addition, the Parental Educative Social Skills Interview Scrip - ESS-IS-P - (Bolsoni-Silva et al., 2016b) and the Social Skills Questionnaire - Parents Version - SSQ-P - (Bolsoni-Silva, Marturano, \& Loureiro, 2011) instruments were validated considering the combined samples of school and preschool children, demonstrating the usefulness of grouping them into a single group.

Access to this paired sample was gained through contact with a large number of schools and mothers as will be described in the procedure section.

The G1 and G2 groups were compared regarding the sociodemographic variables. No significant differences were found in the variables: (a) family income $\left(x^{2}=1.043 p=.594\right)$ and (b) number of children living in the household $\left(\mathrm{x}^{2}=3.298, p=.192\right)$, however, a significant difference in maternal education was identified $\left(x^{2}=7.200, p=.007\right)$. In the nonclinical group, the majority of mothers had more than eight years of schooling ( $n=14)$, whereas in the clinical group the majority of them had up to eight years of schooling $(n=12)$. In order to verify the influence of this variable, binary logistic regression analysis was applied, which verified that maternal education did not influence the behavior problems of the children $(p=.118)$.

\section{Instruments}

Used for sample composition. The CBCL "Child Behavior Checklist", for preschool and school aged children, investigates the frequency of 113 responses indicative of behavior problems, allowing the classification of clinical, borderline, and nonclinical scores for the internalizing, externalizing and total problems scales. Bordin, Mari, and Caeiro (1995), in the preliminary validation, found satisfactory test-positivity and morbidity criteria for the clinical and nonclinical profiles for the 4 to 18 years age group version. The ASEBA software, which accompanies the instrument, also organizes the data into syndromes and subscales based on the DSM (Diagnostic and statistical manual of mental dis- 
orders), such as aggressive behavior, anxiety/depression, oppositional defiant problems, anxiety problems, attention problems, attention deficit hyperactivity disorder and somatic complications. The borderline scores were considered to be clinical, as recommended by Achenbach and Rescorla (2001). The instrument is widely used in the world, considered the gold standard for the evaluation of behavior problems, with psychometric studies being conducted in Brazil (Bordin et al., 2013).

The Parental Educative Social Skills Interview Script (ESS-IS-P, Bolsoni-Silva et al., 2016b), is a semi-structured interview that describes and assesses the diversity and frequency of the social interactions between parents and children. For example, one question asks how often the mother talks to her child (frequency) and then asks what she talks to the child about (diversity). Behavior classes are interactions that occur in terms of communication, expression of feelings, confrontation and the establishing of limits. For each of these classes there is the identification of parenting social skills (positive practices, such as giving explanations, praising, thanking, caressing, setting rules, talking about right and wrong, talking about subjects of interest, encouraging, playing, feeling good), negative practices (physical punishment, threats, cursing/shouting, punishment and withdrawal of privileges), complaints of behavior problems, and childhood social skills. The instrument also has questions that investigate the marital relationship in relation to the parenting practices. Preceding the specific questions, information is collected on: education, marital status, socioeconomic level and work outside the home. The instrument has good psychometric properties regarding internal consistency (alpha 0.846), discrimination of behavior problems, association with social skills and social interaction factors. The instrument differentiated groups that sought psychological care and groups of children with and without behavior problems evaluated by the CBCL. Regarding the construct validity, two factors were found: the first grouped parental PSS, context variables and children's social skills, with the second composed of negative practices and complaints of behavior problems.

Social Skills Questionnaire - Parents Version (SSQ-P), which assesses the frequency of social skills, according to parents' reports (Bolsoni-Silva et al., 2011). The instrument, which presented reliability, discriminate validity and an alpha of 0.82 in the validation, differentiated children with and without behavior problems according to the evaluation of mothers and teachers.

Family Environment Resource Inventory - FERI (Marturano, 2006). This instrument measures the quality of the family environment regarding support in school routines (e.g., homework supervision), interaction opportunities (e.g., walks) and resources in the physical environment (e.g., toys). The total score corresponds to the sum of the scores obtained. The instrument presents a positive association with indicators of social competence and adjustment and a satisfactory internal consistency of 0.84 .

\section{Data Collection Procedure}

After approval by the Research Ethics Committee - CEP, the first step was to obtain authorization from the Department of Education of a medium-sized city in the state of São Paulo. Following this, 16 Early Childhood Education Schools (ECESs) and 16 Elementary Education Schools (EESs) were contacted and invited to participate in the study. The steps regarding the composition of the sample will be described below.

The teachers of the EESs and ECESs of the same geographical location were invited to indicate children with and without behavior problems, with $26 \%$ of them agreeing to participate (62 from ECESs and 72 from EESs), making a total of 134 teachers, who indicated one child without and another with behavior problems. The parents/caregivers of the 268 children indicated were invited to participate in the study, via telephone contact or in person when the children were entering or leaving the school, of whom 183 accepted (68.2\%). Of these, 121 of them were mothers, married or living in consensual 
union and were selected for the present study. The other 62 were single women, widowers, fathers or other caregivers and were not included considering the inclusion criteria regarding biparental families.

With the sample of 121 eligible participants, the mothers of the preschool and school aged children responded to the CBCL "Child Behavior Checklist" (Achenbach \& Rescorla, 2001). Based on the data from this instrument, 32 children with internalizing problems only and 10 with externalizing problems only were identified and excluded from the study, while 26 children with externalizing and internalizing problems were identified and selected for the present study. Among the children with internalizing and externalizing problems in the general scales of the instrument, 4 were girls and 22 were boys considered clinical for internalizing and externalizing problems. A second exclusion criterion was to verify among the clinical boys whether they also scored on the CBCL subscales for both internalizing and externalizing problems, since they could have scored on the general scale, but not on the specific subscales. With the implementation of this criterion 4 boys were excluded, since 3 of them scored only on the internalizing problems subscale and one of them only on the externalizing problems subscale. Thus, the final G1 sample consisted of 18 boys with internalizing and externalizing problems, according to the subscales and total CBCL scores. For the nonclinical G2 group, 18 boys were selected from the 53 nonclinical children (24 girls and 29 boys), considering an equal distribution between preschool and school aged children and the other socio-demographic variables.

Initial information on these 36 children included in the study was provided by their teachers, who presented the following characteristics: mean age of 38.3 years $(S D=9.38)$; higher education; and working in more than one school. It was also noted that the children attended classes with a mean of 25.4 students $(S D=6.21)$.

The family members that agreed to participate signed a consent form and the instruments were applied in the place of their choice (at home, at school or at the Center for Applied Psychology of the university). First the ESS-IS-P was applied by a psychologist with training in the use of the instruments and, subsequently, the CBCL and SSQ-P, in a session of approximately one hour.

\section{Procedure for Processing and Analyzing the Data}

The instruments were corrected according to their instructions. The ESS-IS-P was analyzed regarding the total scores and behavior items, in terms of both diversity and frequency. The CBCL was computed using the ASEBA software and the children were identified as having internalizing and externalizing problems or as nonclinical considering the total scores. For the SSQ, the total score of the child's social skills was used. All of these variables were compared between the group with behavior problems (G1 clinical - internalizing and externalizing) and the group without behavior problems (G2 nonclinical), either for continuous (MannWhitney test) or for categorical measures (Chisquare test). Spearman's correlation analyses were performed with the entire sample separated into clinical and nonclinical. According to Marôco (2014) values lower than 0.25 are considered weak correlations, between 0.26 and 0.50 moderate, between 0.51 and 0.75 strong and above 0.75 the correlations are considered very strong. The level of significance was set at 5\%. Non-parametric analyses were chosen even though the samples had a normal distribution, considering the normality criterion (Kolmogorov-Smirnov test), because they had $n$ less than 30 participants, 18 participants in each group. This was choice was made considering the recommendation of Curado, Teles, and Marôco (2013) that recommend

... with small samples . . . it could be said that the researchers should have used non-parametric inference, since this does not require the specification of a population model, unlike the case in parametric inference... (p. 454) 


\section{Ethical Procedures}

The study was approved by the Research Ethics Committee of the university in which it was performed; being part of a larger project with the title Health, Social, Marital and Parenting Skills: comparisons regarding education, gender and behavior problems (Process no. $5826 / 46 / 01 / 10)$.

\section{Results}

The results section first presents the comparisons between Groups G1 and G2 regarding the general scores of the instruments used to present, in sequence, the items that differentiated the groups from the ESS-IS-P. The section finishes with the results of the correlations performed.

Table 1

Comparisons of the Categorical and Continuous Variables for the G1 and G2 Groups Regarding the Total Scores of Maternal Parenting Practices Evaluated through the ESS-IS-P, SSQ-P and FERI

\begin{tabular}{|c|c|c|c|c|c|}
\hline \multicolumn{6}{|c|}{ Categorical variables } \\
\hline Categories & Subcategories & G1 & $\mathrm{G} 2$ & $X^{2}$ & $P$ \\
\hline \multirow{2}{*}{ Positive Practices: ESS- diversity } & clinical & 12 & 9 & \multirow{2}{*}{1.029} & \multirow{2}{*}{.310} \\
\hline & nonclinical & 6 & 9 & & \\
\hline \multirow{2}{*}{ Positive practices: ESS-frequency } & clinical & 2 & 16 & \multirow{2}{*}{0.000} & \multirow{2}{*}{1.000} \\
\hline & nonclinical & 2 & 16 & & \\
\hline \multirow{2}{*}{ Negative practices: diversity } & clinical & 14 & 6 & \multirow{2}{*}{7.200} & \multirow{2}{*}{.007} \\
\hline & nonclinical & 4 & 12 & & \\
\hline \multirow{2}{*}{ Negative practices: frequency } & clinical & 6 & 0 & \multirow{2}{*}{7.200} & \multirow{2}{*}{.007} \\
\hline & nonclinical & 12 & 18 & & \\
\hline \multicolumn{6}{|c|}{ Continuous variables } \\
\hline Categories & $\begin{array}{c}\mathrm{G} 1 \\
\text { Mean }(S D)\end{array}$ & & $\begin{array}{l}\mathrm{G} 2 \\
\mathrm{n}(S D)\end{array}$ & & $P$ \\
\hline Positive practices: ESS- diversity & $8.83(3.90)$ & & $(4.00)$ & & .696 \\
\hline Positive practices: ESS-frequency & $9.28(2.61)$ & & $(3.03)$ & & .389 \\
\hline Negative practices- diversity & $8.28(3.18)$ & & $(4.39)$ & & .024 \\
\hline Negative practices- frequency & $8.72(3.06)$ & & $(2.89)$ & & .001 \\
\hline Social skills -ESS-IS-P div & $10.22(5.06)$ & & $(4.97)$ & & .988 \\
\hline Social skills -ESS-IS-P freq & $7.06(3.17)$ & & $(3.27)$ & & .389 \\
\hline Complaints of problems -ESS-IS-P div & $9.39(4.39)$ & & $(4.96)$ & & .068 \\
\hline Complaints of problems- ESS-IS-P freq & $0.50(0.86)$ & & $(1.09)$ & & .815 \\
\hline Total positive & $45.39(13.14)$ & & $(16.62)$ & & .719 \\
\hline Total negative & $26.89(7.54)$ & & $(11.40)$ & & .011 \\
\hline Social Skills - SSQ-P & $29.33(5.05)$ & & $2(3.15)$ & & .037 \\
\hline Resources - FERI & $66.00(13.03)$ & & $(12.46)$ & & .017 \\
\hline
\end{tabular}

Note. Expressed items with statistical differences. 
From Table 1 it can be seen that negative practices (hitting, cursing, fighting, punishment, withdrawing privileges, blackmail) differentiate the G1 and G2 groups, both in terms of diversity and behavioral frequency, which impacted on the negative total, which is the sum of these practices, with complaints of behavior problems.
From the perspective of the SSQ-P, the boys with problems were less skilled. Regarding the environmental resources measured by the FERI, the clinical children presented lower mean values. Table 2 describes the comparisons between groups $\mathrm{G} 1$ and $\mathrm{G} 2$ regarding the parenting practices and the child's behaviors.

Table 2

Comparisons Related to the Continuous Variables for Groups G1 and G2 Regarding Maternal Parenting Practices and Children's Behaviors Assessed through the ESS-IS-P. Expressed Items with Statistical Differences

\begin{tabular}{lccc}
\hline Categories & $\begin{array}{c}\text { G1 } \\
\text { Mean }(S D)\end{array}$ & $\begin{array}{c}\text { G2 } \\
\text { Mean }(S D)\end{array}$ & $P$ \\
\hline Hits & $0.44(0.62)$ & $0.00(0.00)$ & .047 \\
Feels bad & $2.83(1.20)$ & $1.22(1.06)$ & .000 \\
Talks about various topics & $0.78(0.88)$ & $1.78(1.56)$ & .051 \\
Child's social skills when the mother talks & $0.61(0.50)$ & $1.28(0.75)$ & .011 \\
Identifies behaviors that they disapprove of & $1.89(0.32)$ & $1.22(0.73)$ & .007 \\
Difficulty in keeping promises & $0.94(0.80)$ & $0.39(0.61)$ & .047 \\
Couple agree & $0.94(0.94)$ & $1.61(0.70)$ & .047 \\
Couple think differently & $1.00(1.03)$ & $0.33(0.49)$ & .029 \\
\hline
\end{tabular}

The ESS-IS-P items that differentiated the groups with and without behavior problems were identifying behaviors that they disapprove of, using the negative practice of hitting and feeling bad, all more frequent in the G1 group. On the other hand, in the nonclinical G2 group, the mothers talked about different topics and the children were more skillful at these times. Concerning the parental understanding in relation to raising the children, it was noted that in G1 there was more difficulty in fulfilling promises, less parental agreement and there were more reports that the couple think differently about raising the children. Although there were no differences between the groups, positive parenting practices had a higher mean values for the nonclinical G2 group. This information is presented to indicate trends in these groups evaluated regarding the Demonstration of affection: (a) Express positive feelings $(\mathrm{G} 1=1.72 ; \mathrm{G} 2=1.94)$, Praise $(\mathrm{G} 1=0.88$; $\mathrm{G} 2=1.17)$, Stimulate $(\mathrm{G} 1=0.27 ; \mathrm{G} 2=0.44)$ Play
(G1 $=0.28 ; \mathrm{G} 2=0.44) ;(\mathrm{b})$ Establish limits: Talk to express negative feelings $(\mathrm{G} 1=0.38$; $\mathrm{G} 2=0.77$ ), talk about right and wrong $(\mathrm{G} 1=1.05 ; \mathrm{G} 2=0.72)$, give explanations $(\mathrm{G} 1=0.22 ; \mathrm{G} 2=0.61)$, establish rules $(\mathrm{G} 1=0.22 ; \mathrm{G} 2=0.67)$ and feel good about establishing limits $(\mathrm{G} 1=0.27$; $\mathrm{G} 2=0.67)$.

According to Table 3, differentiated patterns for groups G1 and G2 can be noted. In the Clinical G1 Group, there was a strong and very strong correlation between positive parental practices, diversity of interaction contexts and resources of the environment measured through the FERI. In the Nonclinical G2 Group the children's social skills were very strongly correlated with positive practices and diversity of interaction contexts, while complaints of behavior problems were very strongly correlated with negative practices, with these negative practices having a negative and moderate correlation with resources of the environment. 
Table 3

Correlations, in the Groups with Externalizing-Internalizing Behavior Problems (G1) and without Behavior Problems (G2), between Parenting Practices, Environmental Resources, Children's Social Skills and Complaints of Behavior Problems. Spearman's Correlation Test

\begin{tabular}{|c|c|c|c|c|c|c|c|}
\hline Group G1, $n=18$ & 1 & 2 & 3 & 4 & 5 & 6 & 7 \\
\hline 1. Social skills - ESS-IS & 1 & 0.117 & 0.056 & 0.311 & 0.339 & 0.426 & 0.159 \\
\hline 2. Social Skills - SSQ & & 1 & 0.466 & 0.283 & -0.012 & 0.323 & -0.072 \\
\hline 3. Behavior problems reported & & & 1 & 0.216 & 0.026 & 0.156 & 0.153 \\
\hline 4. Positive practices & & & & 1 & $0.525 *$ & 0.220 & $0.708 * *$ \\
\hline 5. Context & & & & & 1 & 0.170 & 0.294 \\
\hline 6. Negative practices & & & & & & 1 & 0.135 \\
\hline 7. Resources FERI & & & & & & & 1 \\
\hline Group G2, $n=18$ & 1 & 2 & 3 & 4 & 5 & 6 & 7 \\
\hline 1. Social skills - ESS-IS & 1 & 0.120 & 0.392 & $0.826 * *$ & $0.854 * *$ & 0.387 & 0.038 \\
\hline 2. Social Skills - SSQ & & 1 & -0.376 & 0.346 & 0.337 & -0.459 & 0.293 \\
\hline 3. Behavior problems reported & & & 1 & 0.305 & 0.277 & $0.745 * *$ & -0.110 \\
\hline 4. Positive practices & & & & 1 & $0.669 * *$ & 0.244 & 0.001 \\
\hline 5. Context & & & & & 1 & 0.140 & 0.193 \\
\hline 6. Negative practices & & & & & & 1 & $-0.490 *$ \\
\hline 7. Resources FERI & & & & & & & 1 \\
\hline
\end{tabular}

Note. Expressed items with statistical differences. ${ }^{*}$ The correlation is significant at the 0.05 level (2-tailed); ** The correlation is significant at the 0.01 level (2-tailed).

\section{Discussion}

The present study compared a group of children with concomitant internalizing and externalizing behavior problems with a nonclinical group considering parental practices and childhood behaviors and also verified correlations between these variables. Martin et al. (2014) verified that children with comorbidity disorders present the most functional difficulties regarding school performance and other behaviors, being, therefore, a group with greater vulnerability.

When analyzing childhood behavior problems, it is necessary to consider the effect of sociodemographic variables, including the gender of the child, family income, family configuration and education, which may impact on the occurrence of these problems (Bayer et al., 2006). Considering this hypothesis in the preliminary analyses, the sociodemographic profile of the sample was evaluated and it was verified that the clinical and nonclinical groups of preschool and school aged children were equivalent regarding the sociodemographic variables, such as number of siblings and family income. As the mothers in the nonclinical group had a higher level of education, bivariate logistic regression analysis was applied and it was verified that this variable did not impact on the behavior problems. Thus, some of these variables were controlled in the composition of the sample (family configuration, gender of the respondent and gender of the child), while the others did not differentiate the groups or had no influence on the behavior of interest. The schooling of the child can also impact on the occurrence of behavior problems, with school aged children presenting more problems, according to reports of teachers (Bolsoni-Silva et al., 2016) and parents/caregivers (Bolsoni-Silva et al., 2015). For this reason, this variable was controlled in the composition of the groups, however, the school aged children still presented 
more affective problems, which may have impacted on the results encountered. Therefore, it is important to perform further studies that control this measure.

The most frequent problems in the clinical children were aggressive behaviors, anxiety/ depression and oppositional defiant problems, which did not differentiate the preschool children from the school children, in agreement with that found by Bolsoni-Silva et al. (2015), with a sample also evaluated by the mothers. It was found that the childhood social skills were more frequent in the nonclinical group, which is in agreement with other studies (Blandon et al., 2010; Bolsoni-Silva et al., 2016), and may be considered a protective factor for these problems.

Regarding the parenting practices, the negatives practices differentiated the groups, especially hitting and feeling bad, which is also in agreement with other studies in the area (Price et al., 2013; Rovaris, 2015; Trepat et al., 2014; Xing \& Wang, 2013). These studies evaluated boys and girls and used diagnostic instruments to identify the clinical criterion for behavior problems, with Price et al. (2013) using the CBCL, Trepat et al. (2014) using The diagnostic interview for children and adolescents for parents of preschool children and Xing and Wang (2013) applying the Youth Self Report (YSR). Thus, it was verified that regardless of the family members' or the child's own response to behavior problems, a high occurrence of behavior problems was associated with the use of physical punishment. As Vaughan et al. (2013) affirmed in the interaction with difficult children, that is those that simultaneously presented internalizing and externalizing problems, the parents experience more distress and parental stress, which favors dysfunctional interactions, which can be related to the frequent use of hitting behavior, as verified in the present study. The findings of this study disagree with the study by Bolsoni-Silva and Loureiro (2011) that did not find that negative practices differentiated the groups. The results can also be influenced by the instrument used, since in the study by Bolsoni-Silva and Loureiro (2011) the negative practices were evaluated in general, including other behaviors in addition to hitting, such as punishing and withdrawing privileges. Furthermore, children with concomitant internalizing and externalizing problems were not the focus of this study.

In the present study, only hitting, as a specific behavior, differentiated the groups, while the other behaviors evaluated, such as shouting, threatening, saying no without explanation, withdrawing privileges and punishing, occurred with equal frequency between the groups. In this way, it can be considered that aggressive strategies that could be avoided (such as shouting, cursing, saying no without explanation) were also used in the nonclinical group, which seems to be related to cultural patterns of parenting. However, in addition, the mothers used practices such as withdrawing privileges to teach the children to obey and follow rules, practices which can favor the social learning of the children.

The positive practices, measured as the parenting social skills, did not differentiate the groups as a general category, which is in agreement with the findings of previous studies (Bolsoni-Silva \& Loureiro, 2011). They did, however, differentiate the groups with regard to talking about different topics, identifying behaviors that they disapprove of, keeping promises and parental agreement. As specific behaviors of parenting practices, the quality of communication and behaviors that involve establishing limits with consistency were also highlighted, which replicates the findings of other studies (Berry \& O'Connor, 2010; Bolsoni-Silva \& Loureiro, 2011; Borden et al., 2014; Rovaris, 2015).

Affective behaviors did not differentiate the groups in the present study, which is in disagreement with the literature (Berry \& O'Connor, 2010; Bolsoni-Silva \& Loureiro, 2011; Borden et al., 2014), although there was a tendency for these to occur with more frequency in the nonclinical group, which presented higher mean scores. The resources of the family environment, considering availability of toys/games and monitoring of the studying behavior, differentiated the clinical and nonclinical groups, which is in agreement with the findings of Marturano 
(2006). However, this finding is in disagreement with another case-control study performed with a group of children with internalizing problems only (Bolsoni-Silva et al., 2016), suggesting that for children with concomitant externalizing and internalizing problems these parental strategies are more important than for children with internalizing problems only.

Monitoring the child's study activities is critical to teaching obedience and maximizing good academic performance, which appeared to be a failure in the group of mothers assessed in this study. On the other hand, mothers of internalizing children do not fail to monitor, on the contrary, these families are over-demanding, have an excess of monitoring and are not very responsive (Orti et al., 2015; Tandon et al., 2009). Thus, with the findings of this study, it can be assumed that the group of mothers of children with internalizing problems associated with externalizing problems presented parental practices closer to the externalizing profile than to the internalizing one, including failures in communication and in the establishing of limits for obedience and study behaviors.

The correlations of the clinical group evidenced the lack of consistency in the interactions, since, contrary to what was expected, the positive parenting practices were not associated with skillful behaviors (Borden et al., 2014) and the negative ones were not associated with problem behaviors (BolsoniSilva et al., 2016; Borden et al., 2014). However, the correlations in the nonclinical group were similar to those expected (Bolsoni-Silva et al., 2016; Borden et al., 2014), suggesting a greater consistency in the application of parental practices contingent on the children's behaviors. The positive practices were associated with the context variables (Bolsoni-Silva et al., 2016), however, not with the environmental resources, unlike in the study of Bolsoni-Silva et al. (2016), in which these resources were indirectly related to the use of negative practices. This may mean that in this nonclinical group, the greater structure regarding the study environment and the games that the parents provided lead to less need to use negative practices.
Although the children in the clinical group presented internalizing problems, the pattern of interaction was more similar to that of children with externalizing problems. These children may have first presented externalizing behaviors and, over time, may have been rejected by peers and adults (Patterson et al., 1992), configuring the framework for internalizing problems. Thus, early identification of such difficulties in community samples becomes relevant in order to avoid more severe situations in the future (Flett \& Hewitt, 2013; Patterson et al., 1992).

\section{Final Considerations}

Based on the results of the present study, it was possible to identify patterns of behavior in children who presented concomitant internalizing and externalizing problems at a clinical level and in their mothers. The occurrence of more negative practices and deficits in some positive practices were identified, with the lack of communication regarding subjects of interest to the children, fulfillment of promises, parental agreement and consistency in the use of the practices related to children's behaviors being highlighted. A strong point of the study was the method used in the composition of the groups and in the control of variables. However, the sample was small, direct observation of the family interactions was not employed and the study did not include the evaluation of children in another context of development, the school, with teachers as the evaluators, which may be considered in future studies. These data, by evidencing the vulnerability of this group of children that present the concomitance of internalizing and externalizing problems, contribute to the planning of parental guidance actions that consider the particularities of these behavior patterns and of the parenting practices involved.

\section{References}

Achenbach, T. M., \& Rescorla, L. A. (2001). Manual for the ASEBA School-Age Forms \& Profiles. Burlington, VT: University of Vermont, Research Center for Children, Youth, \& Families. 
Barbot, B., Crossman, E., Hunter, S. R., Grigorenko, E. L., \& Luthar, S. S. (2014). Reciprocal influences between maternal parenting and child adjustment in a high-risk population: A 5-year cross-lagged analysis of bidirectional effects. American Journal of Orthopsychiatry, 84(5), 567-580. doi: 10.1037/ort0000012

Bayer, J. K., Sanson, A. V., \& Hemphill, S. A. (2006). Parent influences on early childhood internalizing difficulties. Journal of Applied Developmental Psychology, 27(6), 542-559. https://doi.org/10.1016/j.appdev.2006.08.002

Berry, D., \& O’Connor, E. (2010). Behavioral risk, teacher-child relationships, and social skill development across middle childhood: A child-by-environment analysis of change. Journal of Applied Developmental Psychology, 31(1), 1-14. doi: 10.1016/j.appdev.2009.05.001

Blandon, A. Y., Calkins, S. D., \& Keane, S. P. (2010). Predicting emotional and social competence during early childhood from toddler risk and maternal behavior. Development and Psychopathology, 22(1), 119-132. doi: 10.1017/ S0954579409990307

Bolsoni-Silva, A. T., Levatti, G. E., Guidugli, P. M., \& Marim, V. C. C. (2015). Problemas de comportamento, em ambiente familiar em escolares e pré-escolares diferenciados pelo sexo. Revista Interamericana de Psicologia/Interamerican Journal of Psychology, 49(3), 354-364.

Bolsoni-Silva, A. T., \& Loureiro, S. R. (2011). Práticas educativas parentais e repertório comportamental infantil: Comparando crianças diferenciadas pelo comportamento. Paidéia (Ribeirão Preto), 21(48), 61-71. http://dx.doi. org/10.1590/S0103-863X2011000100008

Bolsoni-Silva, A. T., Loureiro, S. R., \& Marturano, E. M. (2016a). Comportamentos internalizantes: Associações com habilidades sociais, práticas educativas, recursos do ambiente familiar e depressão materna. Psico, 47(2), 111-120. doi: 10.15448/1980-8623.2016.2.20806

Bolsoni-Silva, A. T., Loureiro, S., \& Marturano, E. M. (2016b). Roteiro de entrevista de habilidades sociais educativas parentais (ESS-IS-P). Manual Técnico. São Paulo, SP: Hogrefe.

Bolsoni-Silva, A. T., Marturano, E. M., \& Loureiro, S. R. (2011). Estudos de confiabilidade e validade do questionário de respostas socialmente habilidosas versão para pais - SSQ-P. Psicolo- gia: Reflexão e Crítica, 24(2), 1-9. doi: 10.1590/ S0102-79722011000200003

Bolsoni-Silva, Silveira, A. M. S., Cunha, E. V., Silva, L. L., \& Orti, N. P. (2016). Problemas de comportamento e funcionamento adaptativo no Teacher's Report Form (TRF): Comparações por gênero e escolaridade. Gerais: Revista Interinstitucional de Psicologia, 9(1), 141-155. Retrieved from http://pepsic.bvsalud.org/pdf/ gerais/v9n1/v9n1a11.pdf

Bordin, I. A. S., Mari, J. J., \& Caeiro, M. F. (1995). Validação da versão brasileira do "Child Behavior Checklist" (CBCL) (Inventário de Comportamentos da Infância e Adolescência): Dados preliminares. Revista ABP-APAL, 17(2), 55-66. Retrieved from http://pesquisa.bvs.br/ brasil/resource/pt/psi-1346

Bordin, I. A., Rocha, M. M., Paula, C. S., Teixeira, M. C. T. V., Achenbach, T. M., Rescorla, L. A., \& Silvares, E. F. M. (2013). Child Behavior Checklist (CBCL), Youth Self-Report (YSR) and Teacher's Report Form (TRF): An overview of the development of the original and Brazilian versions. Cadernos de Saúde Pública, 29(1), 13-28. http://dx.doi.org/10.1590/ S0102-311X2013000100004

Borden, L. A., Herman, K. C., Stormont, M., Nidhi Goel, N., Darney, D., Reinke, W. M., \& WebsterStratton, C. (2014). Latent profile analysis of observed parenting behaviors in a clinic sample. Journal Abnormal Child Psychology, 42(5), 731-742. doi: 10.1007/s10802-013-9815-Z

Cozby, P. C. (2003). Métodos de pesquisa em ciências do comportamento. São Paulo, SP: Atlas.

Curado, S., Teles, M. A. V., \& Marôco, J. (2013). Análisis estadístico de escalas ordinales: aplicaciones en el Área de Salud infantil y Pediatría. Enfermería Global, 30, 446-457. Retrieved from http://scielo.isciii.es/scielo.php?script=sci_arttext\&pid $=$ S1695-61412013000200021

Flett, G. L., \& Hewitt, P. L. (2013). Disguised distress in children and adolescents "flying under the radar": Why psychological problems are underestimated and how schools must respond. Canadian Journal of School Psychology, 28(1), 12-27. http://dx.doi. org/10.1177/0829573512468845

Gomide, P. I. C. (2006). Manual do inventário de estilos parentais: Modelo teórico, manual de aplicação, apuração e interpretação. Petrópolis, RJ: Vozes. 
Marôco, J. (2014). Análise de Equações Estruturais (2nd ed.). Pêro Pinheiro, Portugal: ReportNumber.

Martin, V., Granero, R., \& Ezpeleta, L. (2014). Comorbidity of oppositional defiant disorder and anxiety disorders in preschoolers. Psicothema, 26(1), 27-32. doi: 10.7334/psicothema2013.75

Marturano, E. M. (2006). O Inventário de Recursos do Ambiente Familiar. Psicologia: Reflexão e Crítica, 19(3), 498-506. http://dx.doi. org/10.1590/S0102-79722006000300019

Orti, N., Bolsoni-Silva, A. T., \& Vila, M. B. (2015). Assessment of the effects of a parental intervention with mothers of children with internalizing. Advances in Research, 4(5), 279-292. doi: 10.9734/AIR/2015/16181

Patterson, G. R., Reid, J., \& Dishion, T. (1992). Antisocial boys. Santo André, SP: ESETec.

Price, J. M., Chiapa, A., \& Walsh, N. E. (2013). Predictors of externalizing behavior problems in early elementary-aged children: The role of family and home environments. The Journal of Genetic Psychology: Research and Theory on Human Development, 174(4), 464-471. doi: $10.1080 / 00221325.2012 .690785$

Rovaris, J. A. (2015). Análise das comparações e correlações entre problemas de comportamento, práticas Parentais e habilidades sociais (Master thesis, Programa de Pós-Graduação em Psicologia do Desenvolvimento e Aprendizagem, Universidade Estadual Paulista, Faculdade de Ciências, Bauru, SP, Brazil).
Tandon, M., Cardeli, E., \& Luby, J. (2009). Internalizing disorders in early childhood: A review of depressive and anxiety disorders. Child and Adolescent Psychiatric Clinics of North America, 18(3), 593-610. doi: 10.1016/j.chc.2009.03.004

Trepat, E., Granero, R, \& Ezpeleta, L. (2014). Parenting practices as mediating variables between parents' psychopathology and oppositional defiant disorder in preschoolers. Psicothema, 26(4), 497-504. doi: 10.7334/psicothema2014.102

Vaughan, E. L., Feinn, R., Bernard, S., Brereton, M. S. W., \& Kaufman, J. S. (2013). Relationships between child emotional and behavioral symptoms and caregiver strain and parenting stress. Journal Family Issues, 34(4), 534-556. doi: 10.1177/0192513X12440949

Xing, X., \& Wang, M. (2013). Sex differences in the reciprocal relationships between mild and severe corporal punishment and children's internalizing problem behavior in a Chinese sample. Journal of Applied Developmental Psychology, 34(1), 9-16. doi: 10.1016/j.appdev.2012.09.004

(c) B BY The Author(s), 2018. Open Access. This article is distributed under the terms of the Creative Commons Attribution 4.0 International License (http://creativecommons.org/licenses/by/4.0/), which permits unrestricted use, distribution, and reproduction in any medium, provided you give appropriate credit to the original author(s) and the source, provide a link to the Creative Commons license, and indicate if changes were made. 